\title{
Clutch size in the small-sized lizard Eurolophosaurus nanuzae (Tropiduridae): does it vary along the geographic distribution of the species?
}

\author{
Conrado A. B. Galdino ${ }^{1,2} \&$ Monique Van Sluys ${ }^{2}$ \\ 1. Departamento de Biologia, Universidade Federal do Ceará, Campus do Pici, Bloco 906, 60455-760 Fortaleza, CE, Brazil. \\ (galdinoc@gmail.com) \\ 2. Departamento de Ecologia, Instituto de Biologia Roberto Alcantara Gomes, Universidade do Estado do Rio de Janeiro, Rua São \\ Francisco Xavier, 524, Maracanã, 20550-019 Rio de Janeiro, RJ, Brazil. (vansluys@uerj.br)
}

\begin{abstract}
We studied life history traits of females of the lizard Eurolophosaurus nanuzae (Rodrigues, 1981), an endemic species of rock outcrop habitats in southeastern Brazil. During October 2002 and 2003 we sampled three populations in sites that encompass the meridional portion of the geographic range of the species. Clutch size varied from one to three eggs, with most females carrying two eggs. Clutch size did not vary among populations, but was correlated to female body size. Only larger females produced clutches of three eggs. Females of the small-sized E. nanuzae produce eggs as large as those of medium-sized tropidurids, thus investing a considerable amount of energy to produce clutches resulting in high values of relative clutch mass.
\end{abstract}

KEYWORDS. Life history, interpopulational variation, Squamata.

RESUMO. Tamanho da ninhada no lagarto Eurolophosaurus nanuzae (Tropiduridae): há variação ao longo da distribuição geográfica da espécie? No presente trabalho estudamos alguns aspectos da história de vida de fêmeas de Eurolophosaurus nanuzae (Rodrigues, 1981), endêmica dos campos rupestres da cadeia do Espinhaço, sudeste do Brasil. Durante outubro de 2002 e outubro de 2003 amostramos três populações em áreas cuja disposição geográfica engloba a parte meridional da distribuição da espécie. O tamanho da postura variou de um a três ovos, sendo que a maioria das fêmeas produziu uma ninhada de dois ovos. O número de ovos não variou entre as populações mas foi relacionado ao tamanho corporal das fêmeas (apenas as fêmeas maiores produziram uma postura de três ovos). As fêmeas de E. nanuzae produzem ovos de volume equiparável a espécies de médio tamanho corporal, resultando em elevados valores de massa relativa de postura.

PALAVRAS-CHAVE. História de vida, variação interpopulacional, Squamata.

In lizards, differences in growth rates, fecundity, mortality, and sizes of adults and hatchlings occur among populations within the geographic range of a species (e.g. JAMES \& ShINe, 1988; NieWIAROWSKI, 1994; RADDER, 2006; KIEFER et al., 2008) as a result of microevolution (Dunham \& Miles, 1985).

Clutch size is known to vary between lizards from temperate and tropical regions (RAND, 1982), from seasonal and non-seasonal environments (JAMES \& SHINE, 1988) and also among populations of a species (e.g. KIEFER et $a l ., 2008)$. Such variations arise as responses to local environmental conditions (Ferguson et al., 1990; Shine \& ELPHICK, 2001), but may also result from evolutionary processes (Tinkle \& Ballinger, 1972; Shine \& Geer, 1991). Hence, one might expect that life history traits of species with broad geographic ranges will vary in response to different environments along their distribution or to genetic dissimilarities among distinct populations (NIEWIAROWSKI, 1994).

In Tropidurid lizards, clutch size often ranges from one to 14 eggs and, within a species, larger females typically produce larger clutches (VAN SLUYS, 1993; VAN SLUYS et al., 2002; WIEDERHECKER et al., 2002). However, Tropidurus torquatus Wied-Neuwied, 1820 from coastal populations seems to be an exception because clutch size is not related to female body size (KIEFER et al., 2008). Nonetheless, data on geographic differences in life history traits for tropidurids are still needed (but see KIEFER et al., 2008).

The genus Eurolophosaurus Frost, Rodrigues, Grant \& Titus, 2001 comprises at least three species of small to medium-sized lizards: E. amathites (Rodrigues,
1984), E. divaricatus (Rodrigues, 1986) and E. nanuzae (Rodrigues, 1981). Eurolophosaurus nanuzae is endemic to areas of rocky meadows along the Espinhaço mountain range above $900 \mathrm{~m}$ elevation known as Campos Rupestres (Rodrigues, 1981), whereas E. amathites and E. divaricatus occur in association with sandy areas close to the banks of the São Francisco river (PASSONI et al., 2008). Previous information on reproduction for the genus is restricted to one population of E. nanuzae (GALDINo et al., 2003). These lizards reproduce seasonally, females have a mean clutch size of two eggs (one to three), and there is no association between females' body size and clutch size (GALDINo et al., 2003). Herein we present data on clutch size, clutch volume and relative clutch mass of females from three different populations of E. nanuzae, encompassing most of its meridional geographic range.

\section{MATERIAL AND METHODS}

Field work was conducted in three localities above $800 \mathrm{~m}$ elevation along the Espinhaço mountain range (Fig. 1): Diamantina ( $\left(8^{\circ} 25^{\prime} \mathrm{S}, 43^{\circ} 60^{\prime} \mathrm{W}\right)$, Serra do Cipó $\left(19^{\circ} 12^{\prime} \mathrm{S}\right.$, $\left.43^{\circ} 40^{\prime} \mathrm{W}\right)$ and Serro $\left(18^{\circ} 36^{\prime} \mathrm{S}, 43^{\circ} 23^{\prime} \mathrm{W}\right)$. These localities encompass the meridional portion of the geographic distribution of E. nanuzae (PASSONI et al., 2008). In all areas, the habitat is dominated by vegetation associated to rocky habitats forming the Campos Rupestres physiognomy (Giulietti et al., 2000). At the Campos Rupestres predominant plant families are Poaceae, Eriocaulaceae, Velloziaceae and Melastomataceae (GiULIETTI et al., 1987). Climate is markedly seasonal, with the rainy season occurring 
between October and April and the dry season between May and September (NIMER, 1972). Serra do Cipó is the southern limit of occurrence of E. nanuzae, Serro is located $c a .60 \mathrm{~km}$ to the north and Diamantina is the northernmost locality sampled (Fig. 1). Nevertheless, Diamantina is located $c a .480 \mathrm{~km}$ to the south of the northern limit of the species' distribution.

Females were sampled during the reproductive season (October, GALDINO et al., 2003) of 2002 in Diamantina and Serra do Cipó, and 2003 in Serro. Sampling effort was the same in all locations (4 days). Lizards were caught by noosing or by hand. After capture, individuals were killed and fixed with $10 \%$ formalin. All animals were measured with a caliper (nearest $0.1 \mathrm{~mm}$ ) for the snout-vent-length (SVL) and dissected for gonadal inspection. Clutch size was estimated by counting the number of vitellogenic follicles or oviductal eggs. Follicles were considered vitellogenic when they were yellow and larger than $2.0 \mathrm{~mm}$ in diameter (GALDINO et al., 2003). Eggs were weighted with an electronic scale (to nearest $0.001 \mathrm{~g}$ ) and measured in their length and width within one month after collection. Their volumes were estimated as the volume of a prolate spheroid: $4 / 3 \pi \mathrm{ab}^{2}$ were " $a$ " is the half egg length and " $b$ " the half egg width. Specimens are deposited in Museu Nacional do Rio de Janeiro, Rio de Janeiro (MNRJ)

To test for the association of female SVL with clutch size (number of eggs) and between the clutch size and clutch volume we used Spearman rank correlation. Simple linear regression was used to evaluate the relation between females' SVL and clutch volume and, between female SVL and clutch mass (all $\log _{10}$ transformed). We compared clutch size among populations using KruskalWallis test (ZAR, 1999). Relative clutch mass (RCM) was estimated following VITT \& CoNGDON (1978): RCM =CM / FTM, where CM = clutch mass and FTM = female total mass including clutch mass. Statistical analyses were performed using R (R Development CoRe TeAm, 2009).

\section{RESULTS}

We collected 58 females: 18 in Serra do Cipó, 19 in Serro, and 21 in Diamantina. Female body size varied from 35.8 to $60.2 \mathrm{~mm}$ (mean $46.6 \pm 5.8 \mathrm{~mm}$ ) in Serra do Cipó, from 42 to $54.6 \mathrm{~mm}(47.4 \pm 3.8 \mathrm{~mm})$ in Serro, and from 35.6 to $55.8 \mathrm{~mm}(48.2 \pm 5.6 \mathrm{~mm})$ in Diamantina. Females' body size did not differ among sites (Kruskal-Wallis $\mathrm{p}=0.14$ ) (Fig. 2). From these females, six were reproductive in Serra do Cipó, 17 in Diamantina, and 14 in Serro. Reproductive females averaged $47.8 \pm 5.20 \mathrm{~mm}$ in body size (SVL). Nine females, three in each locality, had evidence of producing more than one clutch simultaneously (mean SVL $=54.1 \pm$ $2.5 \mathrm{~mm})$.

Clutch size varied from one to three eggs. From the 37 mature females, three $(8.11 \%)$ had one vitellogenic follicle and/or egg, 27 (78.4\%) two vitellogenic follicles and/or eggs and five (13.5\%) three eggs. There was no difference in clutch size among populations (KruskalWallis $\mathrm{H}=3.74 ; \mathrm{p}=0.15)$. Mean clutch size was $2.01 \pm 0.69$ with a modal value of two eggs. Females carrying eggs were found in Serra do Cipó $(n=7)$ and in Diamantina $(n=6)$, but not in Serro. Due to the small sample size of ovigerous females for each population, and because we found no variation in clutch size among populations, we pooled the data from all populations for the following analysis. Clutch size was associated with female body size $\left(r_{s}=0.47 ; p=0.004 ; n=34\right)$ (Fig. 3). No female smaller than $54.0 \mathrm{~mm}$ had clutches with three eggs. Mean egg volume was $519.05 \pm 95.86 \mathrm{~mm}^{3}$, and mean clutch volume was $1014.88 \pm 211.45 \mathrm{~mm}^{3}$. We found no association between clutch size and egg volume $\left(r_{\mathrm{s}}=0.19 ; \mathrm{p}=0.54\right.$; $\mathrm{n}=12)$. Neither clutch mass $(1.06 \pm 0.23 \mathrm{~g})$ nor clutch volume was related to females' $\operatorname{SVL}\left(\mathrm{F}_{1,10}=3.66, \mathrm{p}=0.08\right.$ and $\mathrm{F}_{1,10}=0.65, \mathrm{p}=0.44$, respectively). Mean relative clutch mass was $0.24 \pm 0.05$ ranging from 0.17 to 0.31 .

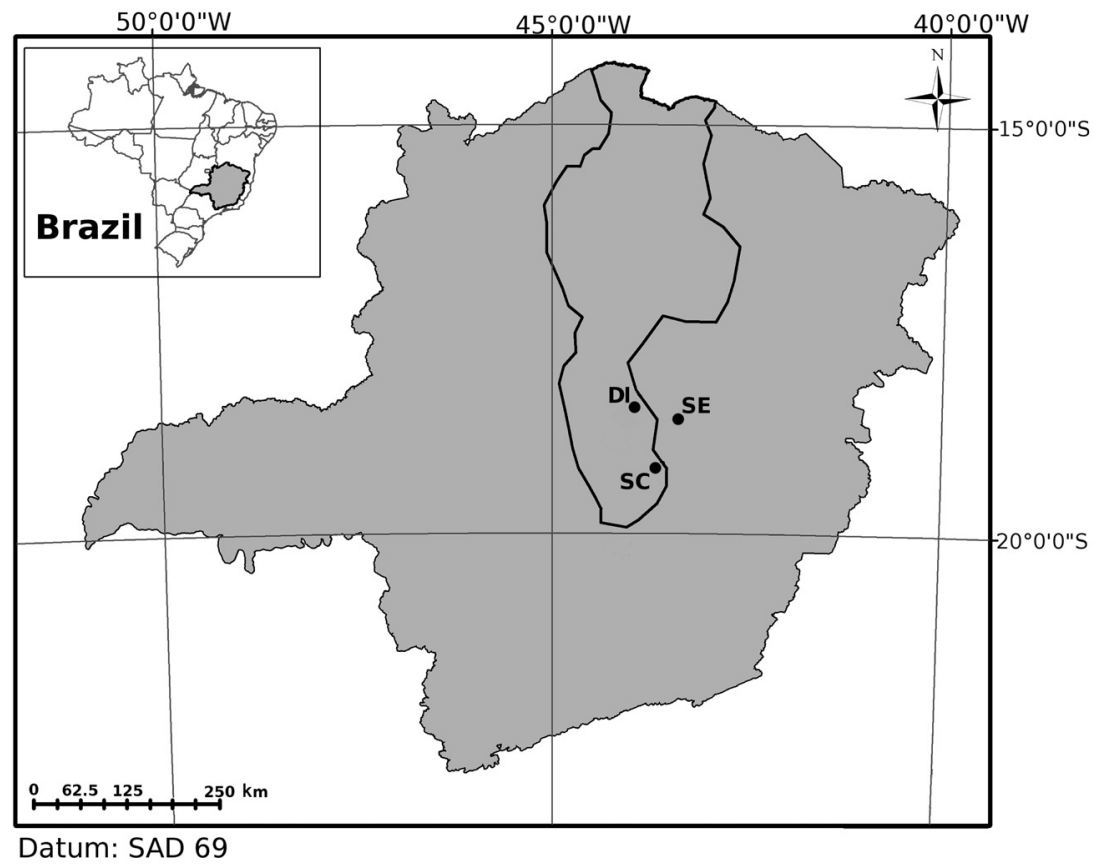

Figure 1. Studied localities at Espinhaço mountain range, Sotheastern Brazil (DI, Dimantina; SE, Serro; SC, Serra do Cipó; dark line, limits of Espinhaço mountain range). 


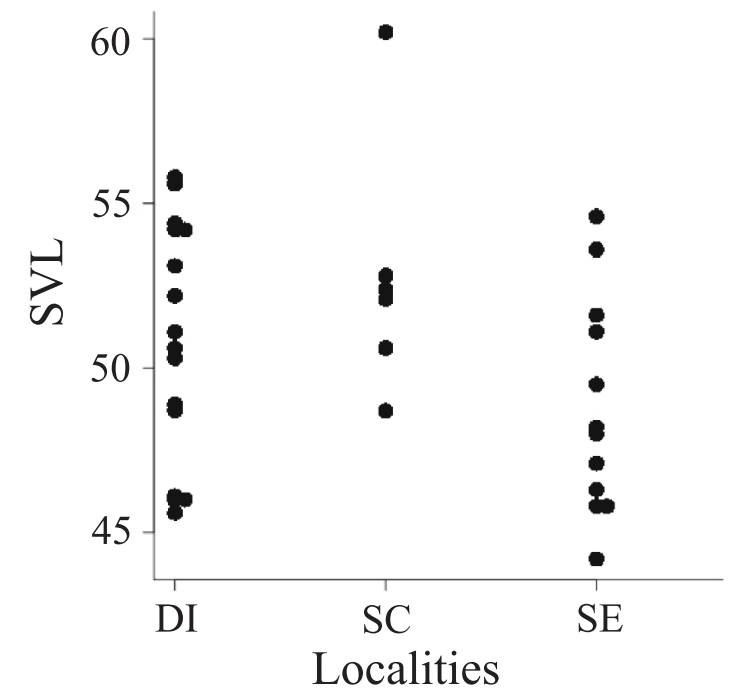

Figure 2. Distribuition of females Eurolophosaurus nanuzae (Rodrigues, 1981) body size (SVL) in Diamantina (DI), Serro (SE) and Serra do Cipó (SC) state of Minas Gerais, MG.

\section{DISCUSSION}

Despite the near invariable clutch size in E. nanuzae, this trait was associated to female body size and only larger (older) females were able to produce clutches with three eggs.

Life history traits in lizards are expected to vary geographically in species with broad geographic distributions as a result of local selective forces (QUALLS \& ShIne, 1997, 1998; Shine \& Downes, 1999; Svensson \& Sinervo, 2000). Nonetheless, clutch size did not vary among populations of $E$. nanuzae. Small-sized lizards have small clutches in general and a relatively invariant clutch may emerge as a result of a small variance in clutch size (SHINE \& GEER, 1991). However, clutch size was related to female body size when data were pooled from all three populations. This result suggests a biological trend for larger females of $E$. nanuzae to produce larger clutches. Only females larger than $54.0 \mathrm{~mm}$ produced clutches of three eggs, despite the low frequency of these large females. In an extensive study on the reproduction of $E$. nanuzae at Serra do Cipó, GALDINo et al. (2003) found no association between clutch size and females' body size, albeit larger females produced clutches of three eggs. Therefore, females' body size affected their fecundity. The adjustment of clutch size to female body size is a pattern commonly found in lizards (Du et al., 2005). In animals with indeterminate growth, body size is correlated with age, thus the larger E. nanuzae females should be the eldest. Because the major cost of reproduction for female lizards is the decrease in their chances of survival and in later reproduction (OLSSON et al., 2001; SvENSSON et al., 2002), and because the energy investment to produce eggs seems to be high for females of $E$. nanuzae (e.g. voluminous eggs and high RCM), we suggest that younger females of $E$. nanuzae might benefit from an increased survival by having a clutch of one or two eggs. Therefore, the largest (eldest) females benefit from a high investment in current reproduction inasmuch as their chances of future reproduction decrease. Since in several

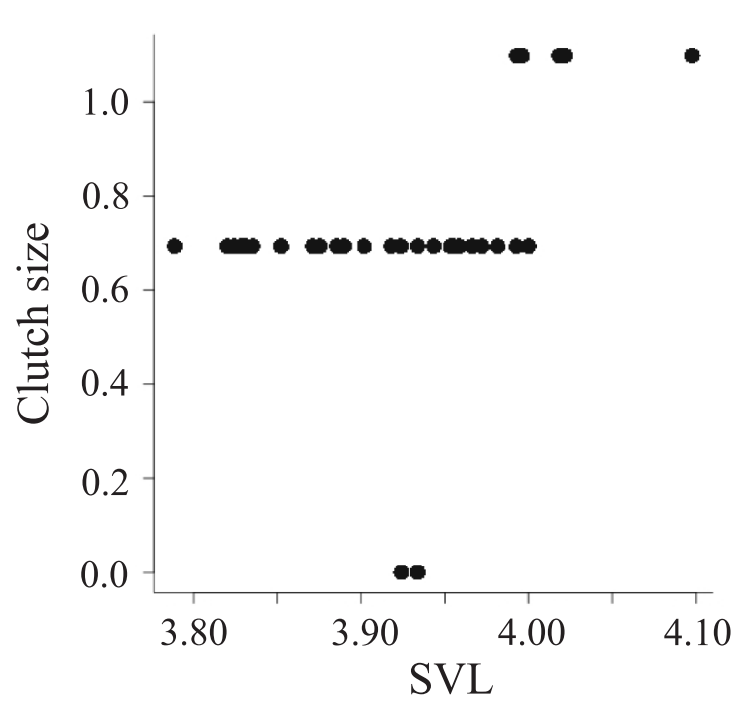

Figure 3. Association between clutch size and female body size (SVL), both log transformed, for Eurolophosaurus nanuzae (Rodrigues, 1981) from three populations from southeastern Brazil.

small-sized lizards the probability of surviving to another reproduction is inversely related to fecundity (TINKLE, 1969), we believe this might be the case in E. nanuzae.

Clutch volume was not associated with female body size. Probably, females of E. nanuzae produced an optimal-sized egg (and/or maternal investment per offspring) in consequence of limitations of their small body size. The lack of an inverse relation between egg volume and clutch size may also constitute an evidence of an optimal egg size for E. nanuzae. Egg volume in $E$. nanuzae is high even when compared to larger tropidurids. As an example, females T. hispidus Spix, 1825 and $T$. torquatus averaged eggs with similar volumes despite their larger body sizes (VITT, 1993; KIEFER et al., 2008). The Relative Clutch Mass of E. nanuzae is also high when compared to other tropidurids (see KIEFER et al., 2008, tab. IV), indicating a considerable high energy allocation in the production of offspring by females. Indeed, E. nanuzae has low rates of locomotion during activity (Mara C. Kiefer, pers. comm.) and uses crypsis as its primary defense strategy (GALDINO et al., 2006), behaviors associated with larger RCM (VITT \& CONGDON, 1978). Therefore, the production of larger individual offspring may constitute a trait increasing the fitness of E. nanuzae.

Acknowledgments. We thank Angélica F. Fontes, Davor Vrcibradic, Thaís Ferreira and Vanderlaine Menezes for help in the field. Geraldo W. Fernandes for permission to work at his property at Serra do Cipó; W. B. Ferreira for preparing the map; Instituto Brasileiro do Meio Ambiente e dos Recursos Naturais Renováveis (IBAMA) for the permit $\left(\mathrm{n}^{\circ} 037 / 02-\mathrm{RAN}\right)$. This study is part of the $\mathrm{PhD}$ thesis of CABG. CABG received fellowship from Coordenação de Aperfeiçoamento de Pessoal de Nível superior (CAPES), currently CABG benefits from a grant from Conselho Nacional de Desenvolvimento científico e Tecnológico (CNPq) (\#151663/20106); MVS received a research grant from CNPq (\# 307773/2008-6).

\section{REFERENCES}

Du, W.; JI, X. \& Shine, R. 2005. Does body volume constrain reproductive output in lizards? Biology Letters 2005:98-100. 
Dunham, A. E. \& Miles, D. B. 1985. Patterns of covariation in life history traits of squamate reptiles: the effects of size and phylogeny reconsidered. American Naturalist 126:231-257.

Ferguson, G. W.; Snell H. L. \& Landwer, A. J. 1990. Proximate control of variation of clutch, egg, and body size in westtexas population of Uta stansburiana stejnegeri (Sauria: Iguanidae). Herpetologica 46:227-238.

Galdino, C. A. B.; Assis, V. B.; Kiefer, M. C. \& Van Sluys, M. 2003. Reproduction and fat body cycle of Eurolophosaurus nanuzae (Sauria; Tropiduridae) from a seasonal montane habitat of southeastern Brazil. Journal of Herpetology 37:687-694.

Galdino, C. A. B.; Pereira, E. G.; Fontes, A. F. \& Van Sluys, M. 2006. Defense behavior and tail loss in the endemic lizard Eurolophosaurus nanuzae (Squamata, Tropiduridae) from southeastern Brazil. Phyllomedusa 5:25-30.

Giullietti, A. M.; Harley, R. M.; Queiroz, L. P.; Wanderley, M. G. L. \& Pirani, J. R. 2000. Caracterização e endemismos nos campos rupestres da Cadeia do Espinhaço. In: Cavalcanti, T. B. \& Walter, B. M. T. eds. Tópicos Atuais em Botânica: palestras convidadas do $51^{\circ}$ Congresso Nacional de Botânica. Brasília, EMBRAPA Recursos Genéticos e Biotecnologia / Sociedade Botânica do Brasil. p.311-319.

Giullietti, A. M.; Menezes, N. L.; Pirani, J. B.; Merguro, M. \& Wanderley, M. G. L. 1987. Flora da Serra do Cipó, Minas Gerais: caracterização e lista das espécies. Boletim de Botânica da Universidade do Estado de São Paulo 9:1-51.

JAMES, C. \& SHINE, R. 1988. Life-history strategies of Australian lizards: a comparison between the tropics and the temperate zone. Oecologia 75:307-316.

Kiefer, M. C.; Van Sluys, M. \& Rocha, C. F. D. 2008. Clutch and egg size of the tropical lizard Tropidurus torquatus (Tropiduridae) along its geographic range in costal eastern Brazil. Canadian Journal of Zoology 86:1376-1388

Niewiarowski, P. H. 1994. Understanding geographic life-history variation in lizards. In: VitT, L. J. \& PiankA, E. R. eds. Lizard ecology: historical and experimental perspectives. New Jersey, Princeton University. p.31-49.

Nimer, E. R. 1972. Climatologia da região sudeste do Brasil: introdução à climatologia dinâmica - Subisídios à Geografia Regional do Brasil. Revista Brasileira de Geografia 34:3-48.

Olsson, M.; Shine, R. \& WaPstra, E. 2001. Costs of reproduction in a lizard species: a comparison of observational and experimental data. Oikos 93:121-125.

Passoni, J. C.; Benozzati, M. L. \& Rodrigues, M. T. 2008. Phylogeny, species limits and biogeography of the Brazilian lizard of the genus Eurolophosaurus (Squamata:Tropiduridae) as inferred from mitochondrial DNA sequences. Molecular Phylogenetics and Evolution 46:403-414.

Qualls, F. J. \& Shine, R. 1997. Geographic variation in 'costs of reproduction' in the scincid lizard Lampropholis guichenoti. Functional Ecology 11:757-763.

1998. Geographic variation in lizard phenotypes: importance of the incubation environment. Biological Journal of the Linnean Society 64:477-491.
R Development Core Team. 2009. R: A language and environment for statistical computing. $R$ Foundation for Statistical Computing. Available at: <http://www.Rproject.org >. Accessed in:14.09.2009.

RADDER, R. S. 2006. An overview of geographic variation in the life history traits of the tropical agamid lizard, Calotes versicolor. Current Science 91:354-1363.

RAnD, A. S. 1982. Clutch and egg size in Brazilian lizards. Herpetologica 38:171-178.

Rodrigues, M. T. 1981. Uma nova espécie de Tropidurus do Brasil (Sauria, Iguanidae). Papéis Avulsos de Zoologia 34(13): 145-149

Shine, R. \& Downes, S. J. 1999. Can pregnant lizards adjust their offspring phenotypes to environmental conditions? Oecologia 119:1-8.

SHINE, R. \& ELPHick, M. J. 2001. The effect of short-term weather fluctuations on temperatures inside lizard nests, and on the phenotypic traits of hatchling lizards. Biological Journal of the Linnean Society 72:555-565.

Shine, R. \& GeER, A. E. 1991. Why are clutch sizes more variable in some species than in others? Evolution 45:1696-1706.

Svensson, E. I. \& Sinervo, B. 2000. Experimental excursions on adaptative landscapes: density-dependent selection on egg size. Evolution 54:1369-1403.

Svensson, E. I.; Sinervo, B. \& Comendant, T. 2002. Mechanistic and experimental analysis of condition and reproduction in a polymorphic lizard. Journal of Evolutionary biology 15:1034-1947

TinkLE, D. W. 1969. The concept of reproductive effort and its relation to the evolution of life history of lizards. The American Naturalist 103:501-516.

Tinkle, D. W. \& BAllinger, R. E. 1972. Sceloporus undulatus: a study of the intraspecific comparative demography of a lizard. Ecology 53:570-584.

VAN Sluys, M. 1993. The reproductive cycle of Tropidurus itambere (Sauria: Tropidurida) in southeastern Brazil. Journal of Herpetology 27:28-32.

Van Sluys, M.; Mendes, H. M. A.; Assis, V. B. \& Kiefer, M. C. 2002. Reproduction of Tropidurus montanus Rodrigues, 1987 (Tropiduridae), a lizard from a seasonal habitat of southeastern Brazil, and a comparison with other Tropidurus species. Herpetological Journal 12:89-97.

VITT, L. J. 1993. Ecology of isolated open formation Tropidurus (Reptilia: Tropiduridae) in Amazonian lowland rainforest. Canadian Journal of Zoology 71:2370-2390.

VitT, L. J. \& Congdon, J. D. 1978. Body shape, reproductive effort, and relative clutch mass in lizards: resolution of a paradox. American Naturalist 112:595-608.

Wiederhecker, H. C.; Pinto, A. C. S. \& Colli, G. R. 2002 Reproductive ecology of Tropidurus torquatus (Squamata: Tropiduridae) in highly Seasonal Cerrado Biome of Central Brazil. Journal of Herpetology 36(1):82-91.

Zar, J. 1999. Biostatistical Analysis. New Jersey, Prentice Hall. 929p.

Recebido em abril de 2010. Aceito em janeiro de 2011. ISSN 0073-4721

Artigo disponível em: www.scielo.br/isz 